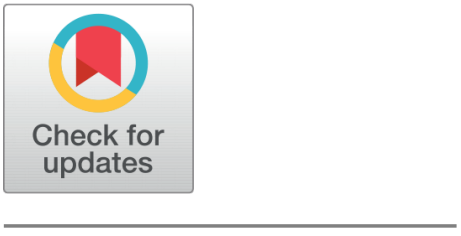

OPEN ACCESS

Received: 31.12 .2020

Accepted: 11.04 .2021

Published: 26.04 .2021

Citation: Najar AA, Ashaq M, Bhat NA, Khare S, Rather AA, Wani AA, Jahangir R (2021) A Diagnostic approach for same looking plants for their Pharmacognosy value. Indian Journal of Science and Technology 14(14): 1105-1115. https://doi.org/ 10.17485/IJST/v14i14.2346

* Corresponding author.

ashaqraza@gmail.com

Funding: None

Competing Interests: None

Copyright: (c) 2021 Najar et al. This is an open access article distributed under the terms of the Creative Commons Attribution License, which permits unrestricted use, distribution, and reproduction in any medium, provided the original author and source are credited.

Published By Indian Society for Education and Environment (iSee)

ISSN

Print: 0974-6846

Electronic: 0974-5645

\section{A Diagnostic approach for same looking plants for their Pharmacognosy value}

\author{
Arshad Ahmad Najar ${ }^{1}$, Mohd Ashaq ${ }^{2 *}$, Nisar Ahmad Bhat ${ }^{3}$, Swati Khare ${ }^{4}$, \\ Arif Ahmad Rather ${ }^{1}$, Ajaz Ahmad Wani ${ }^{1}$, Rabia Jahangir ${ }^{1}$ \\ 1 Department of Botany, Government. Science \& Commerce College Benazir, Bhopal, M.P, \\ India \\ 2 Department of Botany, Government P.G College, Rajouri, 185132, Jammu(1\&K), India \\ 3 Department of Botany, Government Degree College, Billawar, 184204, Kathua, J\&K, India \\ 4 Department of Botany, Government MLB Girls PG Autonomous College, Bhopal (M.P), India
}

\section{Abstract}

Objective: To establish diagnostic features of same looking plants ( $C$. gigantea and $C$. procera) and also to explore the diurnal influence on their Pharmacognosy values. Methodology: To meet the objectives, the characteristics of these plants were explored by macroscopic, microscopic (light microscopy), and also by physio-chemical parameters. The physiochemical analysis was performed with air dried leaves and flowers of $C$. gigantea and C. procera. The collected samples were used for the quantitative determination of ash value (water soluble, acid soluble and sulphate ash values), extractive values, loss on drying, swelling index, and foaming index through standard methods. The leaf and flower extracts (with different solvents) were subjected to qualitative phytochemical screening using the fluorescence test. Further, to explore the diurnal influence, the samples were plucked at different time intervals (morning, afternoon and evening) and fixed immediately for further processing. Results: It was observed that the macroscopic, microscopic and physiochemical characteristics analysed could serve as diagnostic features to distinguish these closely related species. Phytochemically, these plants are rich in constituents like carbohydrates, alkaloids, cardiac glycosides, flavonoids, saponins, phenolic compounds and terpenoids. Moreover, physio-chemical parameters with methanolic extracts provided higher bioactive constituents than other solvents. Besides this, total ash values were found to be maximum i.e. PLA $(15.33 \pm 0.050 \%)$ and GFE $(14.15 \pm 0.031 \%)$ than other acid insoluble and water-soluble values which were under 2-10\%. Pertinently, the moisture content was found little higher in C. gigantea GLA (10.60 $\pm 0.200 \%)$ and GFA $(11.06 \pm 0.100)$ than in C. procera PLA $(8.81 \pm 0.598 \%)$ and PFA $(9.92 \pm 0.244$, while a considerable amount of foaming content was present in both the species was less than 100 . On the basis of observed pharmacognosy, C. procera was found more promising in drug prospective bioactive constituents than C. gigantea and thereby offers more contribution toward establishment of pharmacognostic profile of this medicinally effective plant species. Novelty: Our approach pays a way for the inclusion of an important factor (diurnal 
factor) in assessing the medical efficacy of desired plant species that could help in sampling the specific plant material with desired chemical profile and enhanced pharmacognosy potential.

Keywords: Anatomy; Ash value; Calotropis; Medicinal plants; Stomata;

Trichomes

\section{Introduction}

The variables, like geographical distribution and environmental factors (climate, temperature, altitude, season, and other conditions) and time of harvesting/collection of medicinal plants seem to be important factors related to variation in the active compounds of medicinal plants ${ }^{(1)}$. The ancient physicians were aware about relation between time of collection and distribution of active plant constituents, and impact of different variables on availability of active components in medicinal plants besides the variation in therapeutic efficacy during different times or seasons of the year ${ }^{(2)}$.

The Main hurdle in this context is availability of data/approach for proper characterization of these medicinal plants, in particular, to define variation present between same looking species. The factors like time/place of collection, and way of collection, etc. are important variables that have prime effect on the presence of various bioactive components qualitatively and quantitatively in test samples.

The two same looking plants Calotropis gigantea L. and C. procera L. belong to the family Asclepiadaceae ${ }^{(3)}$. C. procera, locally known as "Aak" in India besides being commonly known as Sodam of apple (Swallow wort in English and Akundia in Hindi) ${ }^{(4)}$ is having enormous medicinal properties which include: use of leaves as pain relieving agents ${ }^{(5)}$, anti-helminthic ${ }^{(6)}$, analgesic, antipyretic, and anti-jaundice effects $^{(7)}$, antimicrobial ${ }^{(8)}$, anti-diarrhoeal, larvicidal, anticancer, cytotoxic ${ }^{(9)}$, and antiinflammatory ${ }^{(10)}$. The flower extracts have antipyretic ${ }^{(11)}$, spermicidal, and anti-fungal properties ${ }^{(7)}$, besides being used for constipation, fever, joint pain and muscular spasm $^{(10)}$, digestive, tonic for asthma and catarrh ${ }^{(4)}$. The other congeneric species studied is C. gigantea, locally known as "Rakta Arka"in India, and commonly as milkweed or wasteland weed ${ }^{(12,13)}$. Its leaves are reported for anti-diarrhoeal, anticandida, and antibacterial activities ${ }^{(14)}$, besides for fever, rheumatism, paralysis, nausea, vomiting, indigestion, cough, cold, eczema and diarrhoea ${ }^{(15)}$. It is also used against asthma and arthralegia swellings ${ }^{(16,17)}$. The flowers are reported to possess analgesic, antimicrobal and cytotoxic effects ${ }^{(18,19)}$ in addition to the stomachic, bechic, and antiasthmatic $^{(20)}$ problems.

The pharmacological and phytochemical research efforts are underway to extraction and characterization of plants for active compounds such as alkaloids, tannins, flavonoids, resins, phenols, fatty acids and steroids which play an important role in human health, and may also be nutritionally important to give birth to high activity profile of new pharmaceutical drugs ${ }^{(21)}$. One of the most difficult tasks in establishing the ethno-botanical value of herbal plants lies in its correct botanical identification ${ }^{(22)}$. However, and comparatively, a lesser amount of research has been done that focuses on identification of same-looking species for their pharmacognosy differences. Further, sunlight plays a key role in initiating a cascade of chemical synthesis starting from photosynthesis itself.

The photosynthates thus generated nourish the plant and also aid in the synthesis of important secondary metabolites that can protect and defend the host against various environmental perturbations. Also, the role of edaphic factor/soil types influencing the pharmacological value have been explored well (Ghasemzadeh et al. $2018^{(23-25)}$. Indeed, good amount of research work is available on exploring these useful secondary metabolites and emphasizing the importance of their extraction procedures ${ }^{(26)}$. Nonetheless, and so far, the least attention has been given on the influence of diurnal 
changes (plucking/harvesting -time) of medicinal herbs as otherwise the diurnal variation (largely influenced by sub-light) is expected to impact the plant physiology including the accumulation of chemical constituents.

In this context, and with regard to the documented medical efficacy of the two congeneric species of Calotropis viz $C$. procera and C. gigantea, present study was undertaken to document the information on micro-morphological features of these plants which would help in their authentication, adulteration and identification. It will also provide the basic pharmacognostic figures required for the herbal pharmacopoeia combination and at the same time to find out the possible diurnal importance on pharmacognosy application. The time of collection of the plant species is anticipated to affect the yield and physio-chemical profile of Calotropis. Nevertheless, published data on such variations is lacking. Therefore, present study has been planned to screen out the effect of time of collection in physio-chemical profile of two same looking Calotropis spp. Thus, this study explores the macro-/micro- characters and phytochemistry of C. gigantea and C. procera leaf and flower vis-à-vis time of collection and their specific physical and chemical standards. The study may be useful as a quality control parameter in the Indian herbal pharmacopoeia.

\section{Materials and methods}

\subsection{Plant collection and authentication}

The aerial parts (leaves and flowers) of the plants were collected in the month of March-April, 2014 from M.P Council of Science and Technology Nehru Nagar (MPCST; $23^{\circ} 15^{\prime} 35.760^{\otimes} \mathrm{N}$ and $77^{\circ} 24^{\prime} 45.414^{\bigotimes} \mathrm{E} ; 1050 \mathrm{~m}$ asl) and P\&T colony, Jawahar chowk (23 $13^{\circ} 25.582^{\bigotimes} \mathrm{N}$ and $77^{\circ} 23^{\prime} 28.294^{\bigotimes} \mathrm{E} ; 900 \mathrm{~m}$ asl), Bhopal, India. The collected plant samples were identified by Dr. Z.H.(Saifia Science College, Bhopal, India). The specimen samples of C. procera and C. gigantea were deposited in the departmental herbarium with respective voucher numbers 481/Bot/SC/2014 and 482/Bot/SC/2014.

\subsection{Macroscopic study}

The macro-morphological features of the collected leaf and flower samples were observed under magnifying lens ${ }^{(27)}$.

\subsection{Microscopic study}

Selected samples of the leaf and flower were stored in FAA solution containing $5 \mathrm{ml}$ formalin, $5 \mathrm{ml}$ acetic acid, and $90 \mathrm{ml}$ of $70 \%(\mathrm{v} / \mathrm{v})$ ethyl alcohol. Fixed for $24 \mathrm{hr}$, the specimens were dehydrated with a graded series of tertiary-butyl alcohol as per the method of Sass ${ }^{(28)}$. The dehydrated samples were casted into paraffin blocks and sectioned with the help of a Rotary Microtome (RMT-30, Radical Instruments, India). The dewaxing of the sections was carried out as per the method described by Johnson ${ }^{(29)}$. The generated sections were finally stained with safranin and mounted in glycerine for microscopic observations

\subsection{Physicochemical analysis}

The physiochemical analysis of air dried leaf and flower of C. gigantea and C. procera was used for the quantitative determination of ash value, extractive value, loss on drying, swelling index, and foaming index through standard methods ${ }^{(30)}$. The total ash value for a crude drug is not always trustworthy since there is a chance of presence of non-physiological substances, such as soil contents, etc. So, the parameters viz water soluble, acid soluble and sulphate ash values were performed. The extractive values with methanol, ethanol, ethyl acetate, chloroform and water were also determined as previously reported ${ }^{(31)}$.

\subsection{Fluorescence analyses}

Fluorescence study of leaf and flower powder was performed as per reported standard procedures ${ }^{(32)}$. A small quantity of the leaf or flower powder was placed in clean Petri plate and 1-2drops of freshly prepared reagent solution was added, gently mixed by tilting and kept as such for a few minutes. It was then placed inside the UV chamber and observed in visible light, short $(254 \mathrm{~nm})$ and long $(365 \mathrm{~nm})$ UV radiations. The colour observed by adding of different reagents in different radiations was recorded.

\subsection{Qualitative phytochemical analyses}

The crude powder of leaf and flower was subjected to qualitative phytochemical analysis ${ }^{(33)}$. The phytochemicals analysed were carbohydrates, proteins, amino acids, alkaloids, flavonoids, tannins, glycosides, terpenoids, steroids and saponins. 


\section{Results}

\subsection{Organoleptic and macroscopic characters}

The organoleptic feature/s of aerial parts of C. gigantea and C. procera is/are given in Table 1 and Figure 1.

Table 1. organoleptic characters of Calotropis of leaf and flower

\begin{tabular}{llll}
\hline Plant parts & Colour & Taste & Odour \\
\hline C. gigantean leaf & Dark green & Aromatic bitter & Characteristic \\
C. gigantean flower & Whitish & Aromatic sweet & Characteristic \\
C. procera leaf & Light green & Aromatic sweet & Characteristic \\
C. procera flower & Light brown & Aromatic bitter & Characteristic \\
\hline
\end{tabular}

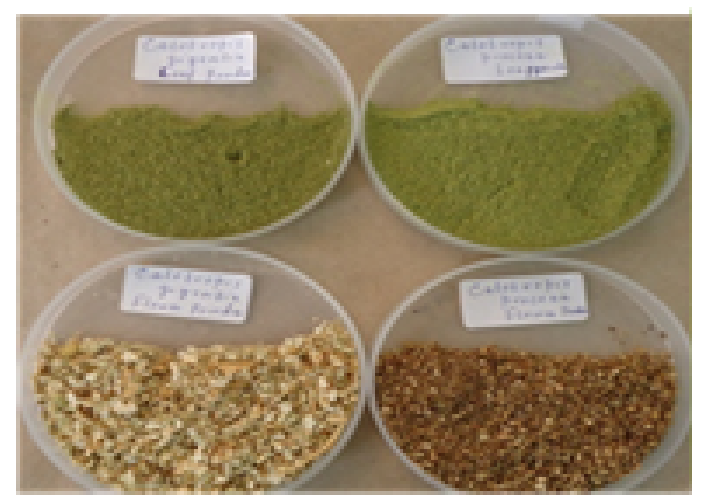

Fig 1. Physical evaluation of Calotropis leaf and flower

The comparative macroscopic characters showed that studied species of Calotropis are perennial shrubs of 5.4 metres height and highly branched. Leaves are opposite, entire, simple and sessile; leaf blade is oblong having short pointed apex and heart shaped base. C. gigantea is large shrub or small tree, $1-5 \mathrm{~m}$ tall, young branches covered with white cottony tomentum, leaves are 3-10 inches long, 2-6 inches wide, thin and elliptic-oblong or obovate-oblong, base cordate, tip acute or shortly acuminate. On the other hand, C. procera is an erect shrub or small tree up to $3 \mathrm{~m}$ tall, much branched from the base, leaves are 3-6 inches long, 2-4 inches wide, thick and elliptic-oblong or obovate-oblong, base cordate, tip acute or shortly acuminate (Figure 2).
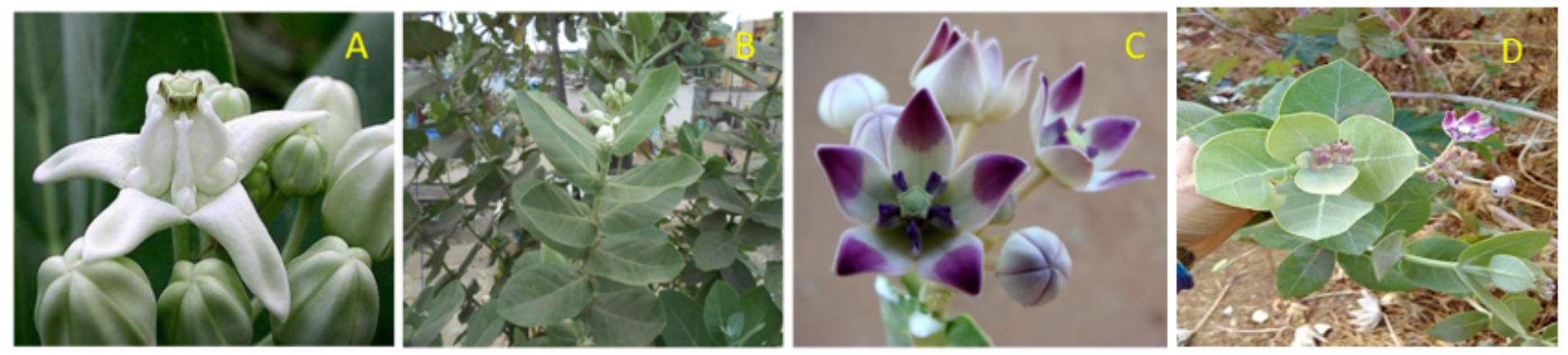

Fig 2. (A-B) C. gigantea with reverse corolla and large thin leaf, (C-D) C. procera with upright corolla and small thick leaf

The comparison of the flowers of these congeneric and closely related species can be used for their identification. The petals in C. gigantea are reflexed (bent in turn round) and $3-4.5 \mathrm{~cm}$ in diameter with white colour, whereas C. procera is distinguished by its erect and divided $2 / 3$ the way down corollas; glaborous; lobes acute and white petals with dark purple tips. Flowering can be observed all the year round (Flora of Madhya Pradesh western part, V.P Singh) (Figure 2). 


\subsection{Microscopic characters}

\subsubsection{Leaf anatomy}

Transverse section of leaf midrib of Calotropis spp. at $\times 10 \times 40 \times$ showed single layered upper and lower epidermis covered with a thick cuticle. Mesophyll was seen differentiated into palisade and spongy tissue. Below the upper epidermis were three rows of elongated and closely arranged parenchyma palisade cells. Spongy parenchyma cells had intercellular spaces and ground tissue composed of bicollateral and open vascular bundles. The lower epidermis showed paracytic open stomata surrounded by many gaud cells as shown in Figure 3 (A-D).
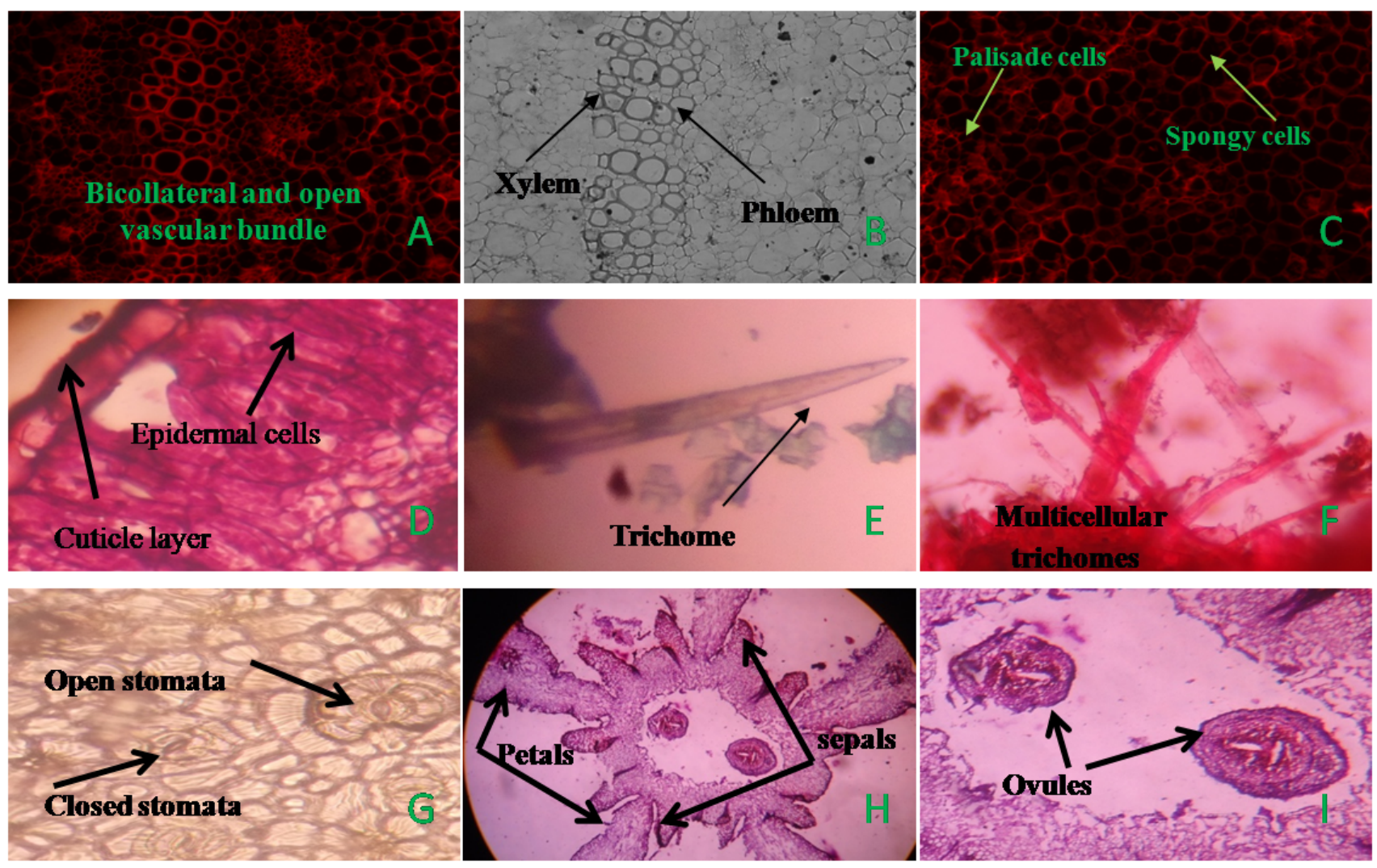

Fig 3. Anatomy of Calotropis Leaf and flower tissues: T.S. of adaxial leaf surface of Calotropis (A-D); Leaf powder showing unicellular (E) and multicellur (F) trichomes in C. procera and C. gigantea, respectively, Paracytic stomata of Calotropis (G); Floral parts of Calotropis (H-I)

\subsubsection{Flower anatomy}

The transverse section of C. gigantea and C. procera flower at $\times 10 \times 40 \times$ showed ovary having ovules (future seed), petals 5 in number (gamopetalous) and sepals also 5 in number (gamosepalous) as shown in Figure 3 (H and I).

\subsubsection{Powder microscopy}

The powder microscopy of leaf of both the Calotropis species at $\times 10 \times 40 \times$ also revealed epidermal cells, vessels, and sclerenchyma cells, besides unicellular and multicellular trichomes in C. procera and C. gigantea, respectively as shown in Figure 3 (E and F). However, the flower powder microscopy did not reveal any kind of structure except the trichomes.

\subsection{Physico-chemical analyses}

The extractive values for various solvents such as ethanol, ethyl acetate, chloroform, methanol and water were assessed here. Efficient extraction was found in the methanol after water for extractive value. Indeed, using different solvents to select good solvent for extraction was our first method to determine which solvent gives the good amount of specific constituents. The 
maximum extractive value with methanolic extracts was found in PFM (19.82\%) and GFA (24.04\%) respectively (Figure 4 A-B).

Extractivevalue

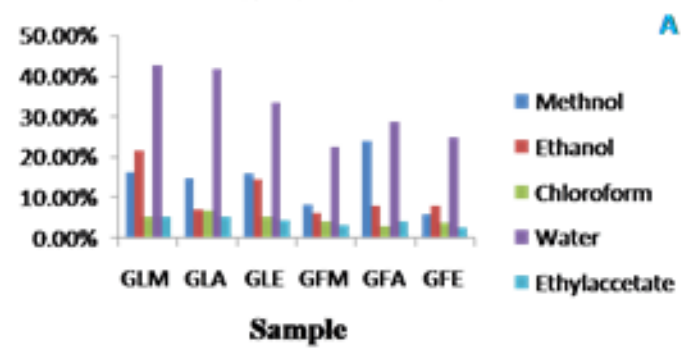

Total ash

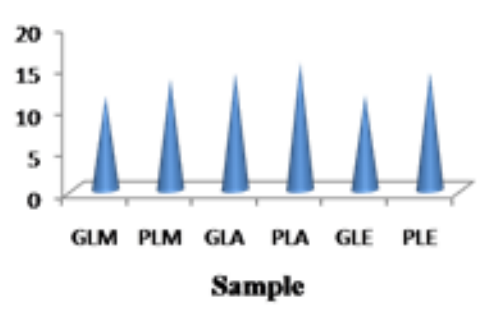

Water soluble Ash

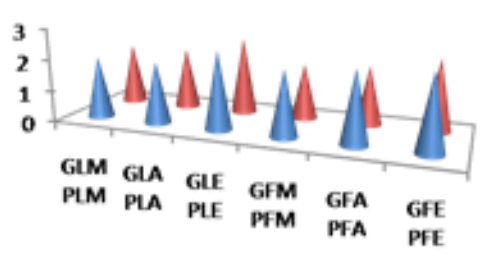

Sample

Moisture content

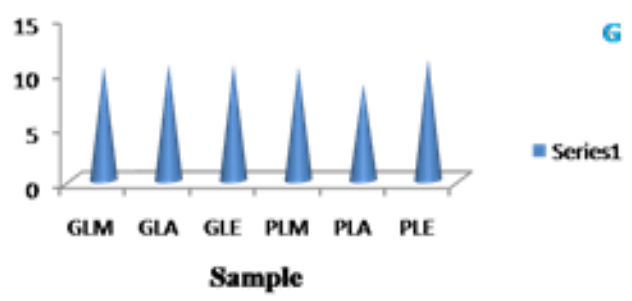

Ieries 1

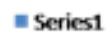

- Series

$\mathbf{E}$

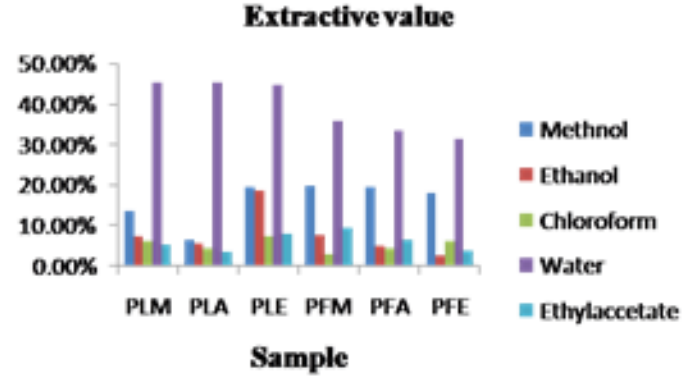

Total ash

D

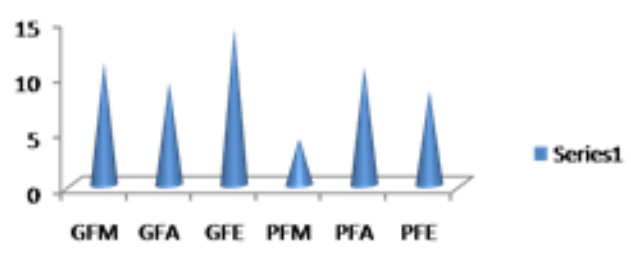

Sample

Sulphate ash

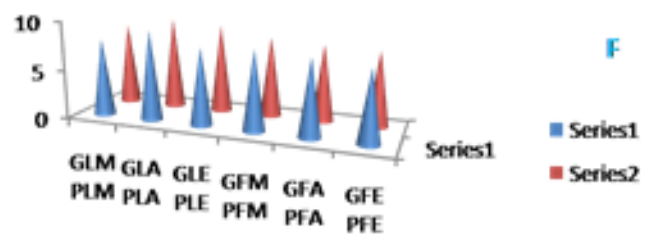

Sample

Moisture content

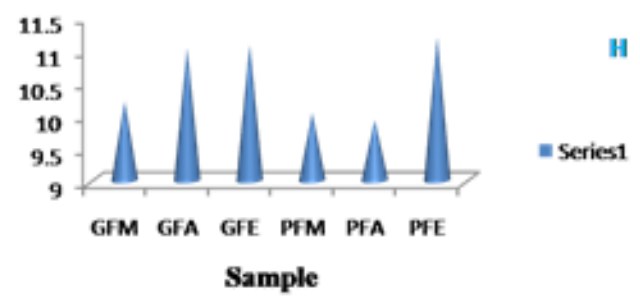

Fig 4. Physiochemical analyses and extractive value of C. gigantea and C. procera; A: extractive value of C. gigantea leaf and flower, B: extractive value of C. procera leaf and flower, C-D: total ash of Calotropis leaf and flower, E-F: water soluble ash and sulphate ash of Calotropis leaf and flower, and G-H: moisture content of Calotropis leaf and flower.

Abbreviations: GLM (Gigantea leaves Morning), GLA (Gigantea leaves Afternoon), GLE (Gigantea leaves Evening) GFM (Gigantea Flowers Morning), GFA (Gigantea Flowers Afternoon), GFE (Gigantea Flowers Evening) PLM (Procera leaves Morning), PLA (Procera leaves Afternoon), PLE (Procera leaves Evening) PFM (Procera Flowers Morning), PFA (Procera Flowers Afternoon), PFE (Procera Flowers Evening).

Spatial and temporal measurements of different parameters of C. gigantea and C. procera showed variable results. The leaf and flower at different intervals of time including morning, afternoon and evening revealed different physio-chemical parameters 
such as ash value (total ash, water soluble ash and sulphate ash), loss on drying and foaming index. Ash constitutes the inorganic residues obtained after complete combustion of a drug. Ash value is a validity parameter to describe and to assess the degree of purity of a crude drug, especially in the powdered form. Total ash was found maximum in PLA (15.33 $\pm 0.050 \%)$ and GFE $(14.15 \pm 0.031 \%)$. Similarly, total ash was found lowest for GLE (11.45 $\pm 0.035 \%)$ and PFM (4.22 $\pm 0.053 \%)$ (Figure 4 C-D).

Water soluble ash was found maximum (2.5\%) both in Calotropis leaf evening (PLE, GLE) and GFE (2.4\%). Similarly, water soluble ash was found lowest in PFM (1.9\%) (Figure 4 E). Sulphate ash was found maximum in PLA (9.5\%) and PFM (8.3\%). Similarly sulphate ash was found lowest in GLE (7.9\%) and GFE (7.3\%) (Figure 4 F). The microbial growth (fungi and bacteria) is promoted when medicinal plants are having access of water. Loss on drying is the loss of mass expressed as percent (w/w), and the test for loss on drying determines both water and volatile matter in the crude drug. Further, moisture is an unavoidable component of crude drug which must be eliminated as far as possible. The moisture content was found maximum in GLA $(10.60 \pm 0.200 \%)$ and GFA (11.06 \pm 0.100$)$, and lowest in PLA (8.81 $\pm 0.598 \%)$ and PFA (9.92 \pm 0.244$)$ (Figure 4 G-H). The foaming ability of an aqueous decoction of herbal materials and their extracts is measured in terms of a foaming index. Foaming index was found more or less same in all samples of C. gigantea and C. procera and was less than 100.

\subsection{Fluorescence analyses}

The phytochemical constituents of the powder material are fluorescent in different wavelengths when illuminated by light. Some phyto-constituents show fluorescence in the visible range ${ }^{(34)}$. Similarly, the ultraviolet light produces fluorescence of natural products (alkaloids) that are not visible in day light. Some crude drugs have been regularly assessed using the fluorescence parameter for their quality. Therefore, the powdered material was made fluorescent by adding various reagents.

Table 2. Fluorescence analysis of powdered leaf and flower of Calotropis spp.

\begin{tabular}{lllc}
\hline Reagent & Colour observed in Ordinary Light & Colour observed under UV Light \\
\hline $\mathrm{N} \mathrm{NaOH}$ & Green /Green & Green/ Green & Green / yellow \\
$\mathrm{N} \mathrm{HCL}$ & Yellow /Green & Green/ Green & Yellow/ Black \\
$0 \% \mathrm{NO} 4 \mathrm{OH}$ & Green /Green & Light Green/Green & Green/ Yellow \\
$0 \% \mathrm{H} 2 \mathrm{SO} 4$ & Yellow/Yellow & Green/ Green & Brown/ Brown \\
\hline
\end{tabular}

Owing to its importance in Pharmacognosy ${ }^{(35)}$, the fluorescence studies of leaf and flower powder of Calotropis spp. at the time of collection showed marked colouration at different wavelengths using different regents due to the light remitted by the molecules during return from the excited to non-excited state. Excited molecules dissipate the absorbed light energy by driving photochemical energy convergent as heat or by emission as fluorescence radiation ${ }^{(36)}$.

\subsection{Preliminary phytochemical screening}

The results of phytochemical qualitative analyses of the crude drug of leaf and flower tissues of Calotropis spp. are as under:

Table 3. Preliminary phytochemical screening of Calotropis spp.

\begin{tabular}{|c|c|c|c|c|c|c|}
\hline Phytochemical compounds & \multicolumn{6}{|c|}{ Methanolic Extracts Leaves and Flowers of Calotropis gigantea and Calotropis procera } \\
\hline Plants Parts & \multicolumn{3}{|c|}{ Time of collection (Leaves) } & \multicolumn{3}{|c|}{ Time of collection (Flowers) } \\
\hline 1.Tests for carbohydrates & Morning & Afternoon & Evening & Morning & Afternoon & Evening \\
\hline & GLM/PLM & GLA/PLA & GLE/PLE & GFM/PFM & GFA/PFA & $\mathrm{GFE} / \mathrm{PFE}$ \\
\hline I.Molish Test & $+/+$ & $+/+$ & $+/+$ & $+/+$ & $+/+$ & $+/+$ \\
\hline II.Fehling's Test & $-/-$ & $-/-$ & $-1-$ & $-/-$ & $-1-$ & $-1-$ \\
\hline III.Benedict's Test & $+/+$ & $+/+$ & $+/+$ & $-1+$ & $+/+$ & $+/+$ \\
\hline \multicolumn{7}{|c|}{ 2.Tests for proteins and aminoacids : } \\
\hline I.Biuret'sTest & $-/-$ & $-/-$ & $-1-$ & $-1-$ & $-1-$ & $-1-$ \\
\hline II.Ninhydrin Test & $-1-$ & $+/-$ & $+/+$ & $-/-$ & $-/+$ & $-1+$ \\
\hline \multicolumn{7}{|l|}{ 3.Tests for Glycosides: } \\
\hline I.Borntrager'sTest & $-1-$ & $-/-$ & $-1-$ & $-/-$ & $-/-$ & $-1-$ \\
\hline II.Legal's Test & $+/+$ & $+/+$ & $+/+$ & $+/+$ & $+/+$ & $+/+$ \\
\hline III.Keller-killiani Test & $-/-$ & $-/-$ & $-1-$ & $-/-$ & $-1-$ & $-1-$ \\
\hline \multicolumn{7}{|l|}{ 4.Tests for Alkaloids: } \\
\hline I.Mayer'sTest & $-1-$ & $-1-$ & $-1-$ & $-/-$ & $-1-$ & $-1-$ \\
\hline II.Dragendrof's Tests & $-/-$ & $-1+$ & $-1-$ & $+/-$ & $-1+$ & $-1-$ \\
\hline
\end{tabular}




\begin{tabular}{|c|c|c|c|c|c|c|}
\hline \multicolumn{7}{|c|}{ Table 3 continued } \\
\hline III.Hager's Test & $-/-$ & $+/+$ & $-1+$ & $-/-$ & $+/+$ & $-/+$ \\
\hline IV.Wagner's Test & $-1+$ & $+/+$ & $+/+$ & $+/+$ & $+/+$ & $+/-$ \\
\hline \multicolumn{7}{|l|}{ 5.Tests for Saponins: } \\
\hline I.Froth Tests & $+/+$ & $+/+$ & $+/+$ & $+/+$ & $-/+$ & $+/+$ \\
\hline \multicolumn{7}{|l|}{ 6.Tests for Flavonoids: } \\
\hline I.Lead Acetate Test & $+/+$ & $+/+$ & $+/+$ & $-1+$ & $+/+$ & $+/+$ \\
\hline II.Alkaline Reagent test & $-1+$ & $+/+$ & $-1+$ & $+/-$ & $+/+$ & $-/+$ \\
\hline III.Shinoda Test & $+/+$ & $+/+$ & $+/+$ & $-1+$ & $-1+$ & $+/-$ \\
\hline \multicolumn{7}{|c|}{ 7.Tests for Triterpenoids and Steriods: } \\
\hline I.Salkowski’s Test & $-/-$ & $-1+$ & $+/-$ & $-/-$ & $+/+$ & $-/-$ \\
\hline II.Libermann-burchard's Test & $-/-$ & $-1+$ & $+/+$ & $+/-$ & $-1+$ & $-/+$ \\
\hline \multicolumn{7}{|c|}{ 8.Tests for Tannin, Phenoliccompounds: } \\
\hline I.Feric chloride Test & $-/-$ & $-/-$ & $-1-$ & $-/-$ & $-/-$ & $-/-$ \\
\hline II.Lead Acetate Test & $-1-$ & $-/+$ & $-1-$ & $-1-$ & $-/+$ & $-/-$ \\
\hline III. Gelatin Test & $-1-$ & $-1-$ & $-1-$ & $-/-$ & $-1-$ & $-/-$ \\
\hline \multicolumn{7}{|l|}{ 9.Tests for fats and oils: } \\
\hline I.Solubility Test & $+/+$ & $+/+$ & $+/+$ & $+/+$ & $+/+$ & $+/+$ \\
\hline
\end{tabular}

${ }^{\star}$ Sign indication: Presence (+) and Absence (-)

\section{Discussion}

Standardization is an essential tool for ensuring the quality control of herbal drugs which is of paramount importance in justifying their acceptability in modern system of medicine ${ }^{(37)}$. The morpho-anatomical variation observed in the C. gigantea and C. procera from the family Asclepiadaceae could be used to distinguish the species for identification ${ }^{(38)}$. Anatomical studies of the Calotropis spp. leaf and flower showed prominent variation in shape and types of stomata and trichomes, shape of epidermal cells, vascular tissue, size and shape of floral parts, all of which could be used in identification of the two plants. Correct identification of medicinal plants is important to detect the adulteration necessary for the sustainable and effective utilization of plant drugs ${ }^{(39)}$. Powder microscopy of Calotropis spp. leaf also showed prominent unicellular and multicellular, epidermal cells and mesophyll cells, but, flower does not show any characters except the trichomes. From current observation of Calotropis spp. that standardization and pharmacognostic analyses will provide the correct identification and authentication which is of the paramount importance in justifying their acceptability in modern system of medicine. Unicellular and multicellular trichomes and paracytic and actinocytic stomata were found on adaxial surfaces in C. procera and C. gigantea, respectively. Thus stomata and trichome character can thus be used as classification and identification parameters in taxonomy as a diagnostic identity tool for this species ${ }^{(40,41)}$. Physicochemical parameters and quantitative screening methods such as aqueous and non-aqueous extract value, total ash value, acid insoluble ash, water-soluble ash, and moisture content are regarded as critical parameters involved in the standardization procedures while evaluating the quality of herbal drug. All these parameters were determined in this study to assess the drug values of Calotropis spp. Further, the maximum extractive value found in PFM and GFA is in agreement with the earlier reports of other researchers as methanol is known to be the efficient solvent for extraction of the phytochemicals from various plant materials ${ }^{(42)}$. Total ash value, water-soluble ash and sulphate ash of Calotropis leaf samples were found maximum in PLA (15.33 $\pm 0.050 \%)$, PLA (2.5\%) and PLA (9.5\%) respectively while the Calotropis flower samples the total ash value, water soluble ash and sulphate ash found maximum in the GFE (14.15 $\pm 0.031 \%)$, $2.4 \%$ and PFM (8.3\%) respectively in time of collection. The highest concentration of physiochemical compounds in test samples were detected in afternoon in leaves of Calotropis procera as compared to Calotropis gigantea. Considering that stimulation factors (light and geography) may play an important role in biosynthesis of plant bioactive compounds. These findings support the observations that the increase in the production of bioactive constituents and variation in percentage to maximum of solar radiation and sample collected seasons ${ }^{(43)}$. Lower moisture content is reported to indicate less chance of microbial degradation of plant drug during storage ${ }^{(44)}$. This is the demarcation with our observation. The general requirement of moisture content in crude drug should not be more than $14 \%{ }^{(45)}$. Moisture content value was found maximum in the sample of leaf GLA (10.60 \pm $0.200 \%)$ and lowest in the PLA $(8.81 \pm 0.598 \%)$ whereas, in the flower sample, moisture content was found maximum in GFA $(10.60 \pm 0.200 \%)$ and lowest in the PFA $(9.92 \pm 0.244)$. Fluorescence analyses showed different colours by different regents between three UV ranges of different plant extracts used for the qualitative assessment of crude drugs ${ }^{(46)}$. The Calotropis spp. appears to be rich in phytochemical constituents widely used in traditional medicines to cure various dreadful diseases. Phytochemical screening showed that the plants contain secondary metabolites such as alkaloids, cardiac glycosides, tannins, terpenoids, and saponins in all samples but particularly was found maximum in the samples collected in the afternoon of 
calotropis. The phytochemical biosynthesis is mediated by environmental factors and even could be seasonal variations. Factors like precipitation, temperature, light, and humidity are critical in affecting the overall yield and major bioactive constituents ${ }^{(47)}$. In this study phytochemicals obtained from collected sample in accordance with the time of collection in afternoon showed maximum yield as compared to other collecting time.

The secondary metabolites are known exhibit various activities against different ailments, and include anti-inflammatory, analgesic, antimicrobial, anticancer and anti-diuretic activities, etc. The present study is purely preliminary attempt to find the conformation based on Ayurvedic principles. Also, it is a qualitative phytochemical study, but, more extensive works on quantification of bioactive components is needed to establish a concrete conclusion about the time of collection. This attempt may bring druggists nearer in achieving specific time of collection and suitable preparation of drug.

\section{Conclusion}

Yield of Calotropis species depends upon the time of collection (morning, afternoon and evening). Maximum yield was obtained in C. procera (leaf and flower parts) as compared to C. gigantea. More variation in phytochemical extraction is due to the time of harvest at which different samples were collected in a day. Pertinently, maximum contents were found a bit higher in afternoon supporting the classical statement for timely collection of different parts of Calotropis species. The Calotropis procera could be feasible harvested in the afternoon for medicinal yield. In nutshell, the current study reveals collection time variation in physio-chemical profile of Calotropis spp. which may serve some purpose to the Indian pharmacopeia.

\section{Acknowledgement}

The author thanks Prof. (Dr.) Swati, Department of Botany Govt MLB Girls PG Autonomous College, Bhopal (M.P), India, and Prof. and Head Dr. Kirti Jain, Department of Botany Govt. Science \& Commerce College Benazir, Bhopal (M.P), India for providing necessary research facilities and guidelines.

\section{Abbreviation}

GLM (Gigantea leaves Morning), GLA (Gigantea leaves Afternoon), GLE (Gigantea leaves Evening) GFM (Gigantea Flowers Morning), GFA (Gigantea Flowers Afternoon), GFE (Gigantea Flowers Evening) PLM (Procera leaves Morning), PLA (Procera leaves Afternoon), PLE (Procera leaves Evening) PFM (Procera Flowers Morning), PFA (Procera Flowers Afternoon), PFE (Procera Flowers Ev)

\section{References}

1) Estabraq HN, Abbas MK, Salam AA. Antibacterial activity and phytochemical investigation of leaves of Calotropis procera plant in iraq by GC-MS. International journal of Pharmaceutical Science and Research. 2019;10(4):1988-1994.

2) Gololo SS, Shai LJ, Agyei NM, Mogale MA. Effect of seasonal changes on the quantity of phytochemicals in the leaves of three medicinal plants from Limpopo province. South Africa Journal of Pharmacognosy and Phytotherapy. 2016;8(9):168-172. Available from: https://doi.org/10.5897/JPP2016.0408.

3) Ali EM, Abdallah BM. Effective Inhibition of Candidiasis Using an Eco-Friendly Leaf Extract of Calotropis-gigantean-Mediated Silver Nanoparticles. Nanomaterials. 2020;10(3):1-16. Available from: https://dx.doi.org/10.3390/nano10030422.

4) Rupali AP, Aakash BM. Anti-hyperbilirubinemic and wound healing activity of aqueous extract of Calotropis procera leaves in Wistar rats. Indian Journal Pharmacolology. 2015;47(4):398-402. Available from: https://dx.doi/10.4103/0253-7613.161262. doi:10.4103/0253-7613.161262.

5) Khan IN, Sarker MMI, Ajrin M. Sedative and anxiolytic effects of ethanolic extract of Calotropis gigantea (Asclepiadaceae) leaves. Asian Pacific Journal of Tropical Biomedicine. 2014;4(1):S400-S404. Available from: https://dx.doi.org/10.12980/apjtb.4.2014c1147.

6) Sharma R, Thakur SG, Sanodiya BS, Savita A, Pandey M, Sharma A, et al. Therapeutic Potential of Calotropis procera: A giant milkweed. IOSR Journal of Pharmacy and Biological Sciences. 2012;4(2):42-57. doi:10.9790/3008-0424257.

7) Pandey A, Swarnkar V, Pandey T, Srivastava P, Kanojiya S, Mishra DK, et al. Transcriptome and Metabolite analysis reveal candidate genes of the cardiac glycoside biosynthetic pathway from Calotropis procera. Scientific Reports. 2016;6(1):34464-34464. Available from: https://dx.doi.org/10.1038/srep34464. doi:10.1038/srep34464.

8) Habib MR, Karim MR. Antimicrobial and Cytotoxic Activity of Di-(2-ethylhexyl) Phthalate and Anhydrosophoradiol-3-acetate Isolated fromCalotropis gigantea(Linn.) Flower. Mycobiology . 2009;37(1):31-36. Available from: https://dx.doi.org/10.4489/myco.2009.37.1.031.

9) Aderounmu AO, Omonisi AE, Akingbasote JA, Makanjuola M, Bejide RA, Orafidiya LO, et al. Wound-Healing and Potential Anti-Keloidal Properties of the Latex of Calotropis Procera (Aiton) Asclepiadaceae in Rabbits. African Journal Traditional Complement Alternernative Medicine. 2013;10(3):574-579. Available from: http://dx.doi.org/10.4314/ajtcam.v10i3.28.

10) Al-Rowaily SL, Abd-ElGawad AM, Assaeed AM, Elgamal AM, Gendy AENGE, Mohamed TA, et al. Essential Oil of Calotropis procera: Comparative Chemical Profiles, Antimicrobial Activity, and Allelopathic Potential on Weeds. Molecules. 2020;25(21):1-19. Available from: https://dx.doi.org/10.3390/ molecules25215203.

11) Awaad AA, Alkanhal HF, El-Meligy RM, Zain GM, Adri VDS, Hassan DA, et al. Anti-ulcerative colitis activity of Calotropis procera Linn. Saudi Pharmaceutical Journal. 2018;26(1):75-78. Available from: https://dx.doi.org/10.1016/j.jsps.2017.10.010. 
12) Wang ZN, Wang MY, Mei WL, Han Z, Dai HF. A New Cytotoxic Pregnanone from Calotropis gigantea. Molecules. 2008;13(12):3033-3039. doi:10.3390/molecules13123033.

13) Sharma M, Tandon S, Nayak U, Kappadi D, Rathore A, Goyal A. Calotropis gigantea extract as a potential anticariogenic agents against Streptococcus mutans: An in vivo comparative evaluation. Journal of Conservative Dentistry. 2017;20(3):174-179. Available from: https://dx.doi.org/10.4103/jcd.jcd_ 13_16.

14) Sharma M, Tandon S, Aggarwal V, Bhat K, Kappadi D, Chandrashekhar P. Evaluation of antibacterial activity of Calotropis gigentica against Streptococcus mutans and Lactobacillus acidophilus: An in vitro comparative study. Journal of Conservative Dentistry. 2015;18(6):457-460. Available from: https: //dx.doi.org/10.4103/0972-0707.168809.

15) Mutiah R, Widyawaruyanti A, Sukardiman S. Calotroposid A: a Glycosides Terpenoids from Calotropis gigantea Induces Apoptosis of Colon Cancer WiDr Cells through Cell Cycle Arrest G2/M and Caspase 8 Expression. Asian Pacific Journal of Cancer Prevention. 2018;19(6):1457-1464. Available from: https://dx.doi:10.22034/APJCP.2018.19.6.1457.

16) Rathod NR, Raghuveer I, Chitme HR, Chandra R. Free Scavenging Activity of Calotropis gigantea on Streptozotocin-Induced Diabetic Rats. Indian Journal of Pharmacuetical Science. 2009;71(6):615-621.

17) Rathod NR, Chitme HR, Irchhaiya R, Chandra R. Hypoglycemic Effect of Calotropis Gigantea Linn. Leaves and Flowers in Streptozotocin-Induced Diabetic Rats. Oman Medical Journal. 2011;26(2):104-108. Available from: https://dx.doi.org/10.5001/omj.2011.26.

18) Kumari P, Panda PK, Jha E, Kumari K, Nisha K, Mallick MA. Mechanistic insight to ROS and Apoptosis regulated cytotoxicity inferred by Green synthesized $\mathrm{CuO}$ nanoparticles from Calotropis gigantea to Embryonic Zebrafish. Scientific Reports. 2017;7(1):1-17. Available from: https://dx.doi. org/10.1038/s41598-017-16581-1.

19) Govindasamy GA, Mydin RBSMN, Sreekantan S, Harun NH. Compositions and antimicrobial properties of binary ZnO-CuO nanocomposites encapsulated calcium and carbon from Calotropis gigantea targeted for skin pathogens. Scientific Reports. 2021;11(1):99. Available from: https: //dx.doi.org/10.1038/s41598-020-79547-w.

20) Parhira S, Zhu GY, Jiang RW, Liu L, Bai LP, Jiang ZH. 2'-Epi-uscharin from the Latex of Calotropis gigantea with HIF-1 Inhibitory Activity. Scientific Reports. 2015;4(1):4748. Available from: https://dx.doi.org/10.1038/srep04748.

21) Fiaz A, Qazi NS. Pharmacognostic study and development of quality control parameters for fruit, bark and leaf of Zanthoxylum armatum (Rutaceae). Ancient Science of Life. 2015;34(3):147-155. Available from: https://dx. doi:10.4103/0257-7941.157159.

22) Abubakar A, Haque M. Preparation of medicinal plants: Basic extraction and fractionation procedures for experimental purposes. Journal of Pharmacy And Bioallied Sciences. 2020;12(1):1-10. Available from: https://dx.doi.org/10.4103/jpbs.jpbs_175_19.

23) Ghasemzadeh A, Jaafar HZE, Bukhori MFM, Rahmat MH, Rahmat A. Assessment and comparison of phytochemical constituents and biological activities of bitter bean (Parkia speciosa Hassk.) collected from different locations in Malaysia. Chemistry Central Journal. 2018;12(1):12. Available from: https://dx.doi.org/10.1186/s13065-018-0377-6.

24) Unander DW, Bryan HH, Lance CJ, Mcmillan RT. Cultivation ofPhyllanthus amarus and evaluation of variables potentially affecting and the inhibition of viral DNA polymerase. Economic Botany. 1993;47(1):79-88. Available from: https://dx.doi.org/10.1007/bf02862208.

25) Sarin B, Verma N, Martín JP, Mohanty A. An Overview of Important Ethnomedicinal Herbs ofPhyllanthusSpecies: Present Status and Future Prospects. The Scientific World Journal. 2014;2014:1-12. Available from: https://dx.doi.org/10.1155/2014/839172.

26) Karimi A, Krähmer A, Herwig N, Schulz H, Hadian J, Meiners T. Variation of Secondary Metabolite Profile of Zataria multiflora Boiss. Populations Linked to Geographic, Climatic, and Edaphic Factors. Frontiers in Plant Science. 2020;11:969. Available from: https://dx.doi.org/10.3389/fpls.2020.00969.

27) Kokate CK. Practical pharmacognosy. 4th ed. and others, editor;New Delhi. Vallabh Prakashan. 2010.

28) Kokate CK. Practical pharmacognosy. 1st ed. New Delhi. Vallabh Prakashan. 2005.

29) Azhagumadhavan S, Senthilkumar S, Padma M, Sasikala P, Jayaseelan T, Ganesan S. A Study on Establishment of Phytochemical Analysis of Quality Parameters and Fluorescence Analysis of Costus spicatus- rhizome extract Medicinal Plants a Well Known Tropical Folklore Medicine. Journal of Drug Delivery and Therapeutics. 2019;9(1-s):240-243. Available from: https://dx.doi.org/10.22270/jddt.v9i1-s.2329.

30) Kumar D, Gupta J, Kumar S, Arya R, Kumar T, Gupta A. Pharmacognostic evaluation of Cayratia trifolia (Linn.) leaf. Asian Pacific Journal of Tropical Biomedicine. 2012;2(1):6-10. Available from: https://dx.doi.org/10.1016/s2221-1691(11)60180-9.

31) Su D, Zhang R, Hou F, Zhang M, Guo J, Huang F, et al. Comparison of the free and bound phenolic profiles and cellular antioxidant activities of litchi pulp extracts from different solvents. BMC Complementary and Alternative Medicine. 2014;14(1):1-10. Available from: https://dx.doi.org/10.1186/14726882-14-9.

32) Shafqat AK, Barkatullah MI. A Pharmacognostic evaluation of the leaf of Rhus succedanea var. Himalaica. j. d hooker. African Journal of Traditional Complement Alternative Medicine. 2016;16(6):107-120. doi:10.21010/ajtcam. v13i6.16 107.

33) Parveen R, Shamsi TN, Singh G, Athar T, Fatima S. Phytochemical analysis and In-vitro Biochemical Characterization of aqueous and methanolic extract of Triphala, a conventional herbal remedy. Biotechnology Reports. 2018;17:126-136. Available from: https://dx.doi.org/10.1016/j.btre.2018.02.003.

34) Zalke A, Duraiswamy B, Gandagule U, Singh N. Pharmacognostical evaluation of Cardiospermum halicacabum Linn. leaf and stem. Ancient Science of Life. 2013;33(1):15-15. Available from: https://dx.doi.org/10.4103/0257-7941.134561. doi:10.4103/0257-7941.134561.

35) Kabra A, Sharma R, Singla S, Kabra R, Baghel US. Pharmacognostic characterization of Myrica esculenta leaves. Journal of Ayurveda and Integrative Medicine. 2019;10(1):18-24. Available from: https://dx.doi.org/10.1016/j.jaim.2017.07.012.

36) Sonibare MA, Oke TA, Soladoye MO. A pharmacobotanical study of two medicinal species of Fabaceae. Asian Pacific Journal of Tropical Biomedicine. 2014;4(2):131-136. Available from: https://dx.doi.org/10.1016/s2221-1691(14)60221-5.

37) Kabra A, Sharma R, Hano C, Kabra R, Martins N, Baghel US. Phytochemical Composition, Antioxidant, andAntimicrobial Attributes of Different Solvent Extracts from MyricaesculentaBuch. Biomolecules. 2019;9(8):357. Available from: https://doi.org/10.3390/biom9080357.

38) Singh P, Khosa RL, Srivastava S, Mishra G, Jha KK, Srivastava S, et al. Pharmacognostical study and establishment of quality parameters of aerial parts of Costus speciosus-a well known tropical folklore medicine. Asian Pacific Journal of Tropical Biomedicine. 2014;4(6):486-491. Available from: https://dx.doi.org/10.12980/apjtb.4.2014c1103.

39) Khan SA, Barkatullah MI. PHARMACOGNOSTIC EVALUATION OF THE LEAF OF Rhus succedanea VAR. HIMALAICA. J. D HOOKER. African Journal of Traditional, Complementary and Alternative medicines. 2016;13(6):107-120. Available from: https://dx.doi.org/10.21010/ajtcam.v13i6.16.

40) Khan SA, Barkatullah MI, Ullah S. Microscopic investigations and pharmacognostic techniques used for the standardization of leaf of Rhus succedanea var. Himalaica J. D. Hook. Microscopy Research and Technique. 2019;82(12):1982-1992. Available from: https://dx.doi.org/10.1002/jemt.23367.

41) Khan SA, Barkatullah, Khan B. Anatomy, micromorphology, and physiochemical analysis of Rhus succedanea var. himalaica root. Microsc Res Tech;83(4):424-435. doi:10.1002/jemt.23430. 
42) Su D, Zhang R, Hou F, Zhang M, Guo J, Huang F. Comparison of the free and bound phenolic profiles and cellular antioxidant activities of litchi pulp extracts from different solvents. BMC Complementary and Alternative Medicine. 2014;14(1):9. Available from: https://dx.doi.org/10.1186/1472-6882-14-9.

43) Ncube B, Finnie JF, Staden JV. Seasonal variation in antimicrobial and phytochemical properties of frequently used medicinal bulbous plants from South Africa. South African Journal of Botany. 2011;77(2):387-396. Available from: https://dx.doi.org/10.1016/j.sajb.2010.10.004.

44) Siraj J, Belew S, Suleman S. Ethnobotanical Assessment and Physicochemical Properties of Commonly Used Medicinal Plants in Jimma Zone, Southwest Ethiopia: Traditional Healers Based Cross-Sectional Study. Journal of Experimental Pharmacology. 2020;12:665-681. Available from: https://dx.doi.org/ 10.2147/jep.s267903.

45) Chumbhale DS, Upasani CD. Pharmacognostic standardization of stems of Thespesia lampas (Cav.) Dalz \& Gibs. Asian Pacific Journal of Tropical Biomedicine. 2012;2(5):357-363. Available from: https://dx.doi.org/10.1016/s2221-1691(12)60056-2.

46) Kumar D, Gupta J, Kumar S, Arya R, Kumar T, Gupta A. Pharmacognostic evaluation of Cayratia trifolia (Linn.) leaf. Asian Pacific Journal of Tropical Biomedicine. 2012;2(1):6-10. Available from: https://dx.doi.org/10.1016/s2221-1691(11)60180-9.

47) Ncube B, Finnie JF, Staden JV. Quality from the field: The impact of environmental factors as quality determinants in medicinal plants. South African Journal of Botany. 2012;82:11-20. Available from: https://dx.doi.org/10.1016/j.sajb.2012.05.009. 